\title{
CRIMMIGRATION IN SLOVENIA
}

\author{
Veronika BAJT', Mojca FRELIH"
}

COBISS 1.01

\section{ABSTRACT \\ Crimmigration in Slovenia}

The article discusses "crimmigration" (i.e. the criminalization of migration) in Slovenia. It evaluates elements of crimmigration in the legal framework, institutions and policies. The analysis of the framing of the topic at the normative level of institutions is accompanied by an examination of the implementation of specific procedures in practice. An exploration of policies and expert opinions is combined with an analysis of the effects that crimmigration has on migrants. Corroborated with the migrants' experience with crimmigration measures, the article concludes that migration policy in Slovenia is becoming stricter and progressively headed in the direction of increased criminalization of migration.

KEY WORDS: crimmigration, Slovenia, migration, asylum

\section{IZVLEČEK}

\section{Krimigracije v Sloveniji}

Avtorici v članku obravnavata »krimigracijo (tj. kriminalizacijo migracij) v Sloveniji. Raziskujeta elemente kriminalizacije migracij $\vee$ pravnem okviru, institucijah in politikah. Uokvirjanje tematike na normativni ravni institucij analizirata skupaj s pregledom izvajanja konkretnih postopkov v praksi, analizo političnih in strokovnih mnenj pa združujeta z analizo učinkov, ki jih imajo krimigracije na migrant(k)e. Ugotavljata, da izkušnje oseb, ki migrirajo, s krimigracijskimi ukrepi potrjujejo, da migracijska politika v Sloveniji, tudi kot posledica izvajanja smernic EU, postaja strožja in vedno bolj usmerjena v povečevanje kriminalizacije migracij.

KLJUČNE BESEDE: krimigracije, Slovenija, migracije, azil

PhD in Sociology, Research Fellow, Peace Institute, Metelkova 6, SI-1000 Ljubljana; veronika.bajt@mirovni-institut.si

॥ MSc in Sociology, Senior Research Assistant, Peace Institute, Metelkova 6, SI-1000 Ljubljana; mojca.frelih@mirovni-institut.si 


\section{INTRODUCTION}

Around the world and especially within the European Union, governments of various stripes have become increasingly quick to deploy criminal justice measures to address the "immigration problem". Existing practices of migration control "disrupt traditional frames of understanding within criminal law and criminology" (Franko Aas 2016: 21), as many national jurisdictions have adopted increasingly restrictive immigration control systems. State borders are subject to increased militarization, progressive securitization and ever-more high-tech surveillance. The convergence of immigration and criminal law has therefore been identified as the most important contemporary development in immigration law (Stumpf 2006). While immigration policies are increasingly based on exclusion and denial of rights with the purpose of control over migrants, migration law is taking on elements of criminal law, which researchers have termed the criminalization of migration or "crimmigration".

Both criminal and immigration law are, at their core, systems of inclusion and exclusion. They are similarly designed to determine whether and how to include individuals as members of society or exclude them from it. Both create insiders and outsiders. Both are designed to create distinct categories of people - innocent versus guilty, admitted versus excluded or, as some say, "legal" versus "illegal”. (ibid.: 380 )

It may seem that current crimmigration trends are a novelty in migration policy, with a rising number of people, most notably politicians, media personalities and even academics claiming that we are witnessing a global migration crisis. Indeed, in recent years the debate about managing migration has shifted to the top of political agenda, yet immigration control has been an important issue in Britain since the late 1950s and in the rest of Western Europe since the mid-1970s (Castels 2010). While it is possible to observe a series of "migration crises" across the world, speaking of a global crisis is a vocabulary used by immigration sceptics and opponents, who reduce the disourse on the migration phenomenon to terminology such as burden, threat, security, risk, and control. In this way, migrations are increasingly considered solely in terms of "management" of people on the move, who in consequence have become de-personalized as "flows" in need of being at least properly channelled, if not stopped entirely. As a consequence, countries that have developed

generally rights-sensitive standards and procedures for assessing protection claims of asylum seekers within their jurisdictions have simultaneously established barriers that prevent migrants, including asylum seekers, from setting foot on their territories or otherwise triggering protection obligations. Consequently, those who would otherwise have been able to avail themselves of asylum procedures, social support, and decent reception conditions are often relegated to countries of first arrival or 
transit that have comparatively less capacity to ensure protection of human rights in accordance with international standards. (Frelick et al. 2016: 190-191)

At the same time, the more nation-states and various supra-national bodies such as the EU attempt to control migration, the more the gap seems to be growing between the aims and actual results of national migration policies. "Undocumented migration, entry of asylum seekers and the formation of new ethnic communities all seem to be driven by forces which governments cannot control" (Castels 2010: 205).

A rise in hate speech against migrants, and in particular Muslims, has been apparent. This is especially the case when taking into consideration the 2015 "refugee crisis" in the EU, although the situation has been deteriorating for people seeking asylum since the 1980s (Peters 2007). Decision-makers justify their actions that exclude a growing number of individuals from society through scapegoating tactics of nationalist and racist prejudice, which instill fear of immigration, even though the research shows hardly any evidence of an immigration-crime nexus. "Migration and asylum seeking are increasingly perceived as phenomena that cause security concerns, and therefore have to be addressed by way of control and punishment" (Kogovšek Šalamon 2017: 251). Using immigration and criminal law as a means of exclusion, an ever-expanding group of outsiders is being denied the basic privileges that are only bestowed upon citizens (Stumpf 2006). Operating in the intersection between criminal and immigration law, migrants are increasingly constructed as "symbolic assailants" (Jiang, Erez 2018) with threatening consequences for their fundamental rights. Detention, expulsion and deterrence have become a predominant policy response to migration (Kogovšek Šalamon 2017: 252), reported to increasingly result in the inability to even claim asylum in the EU. Since the latter has also become a burning issue in Slovenia recently, with pushbacks reported in the Western Balkans that are leading to an increasing number of human rights violations (Regvar 2018), it is necessary to examine this issue more closely.

Studies problematizing asylum and deportation policies (Kogovšek Šalamon 2011; Zorn 2014), integration, social and labour market policies (Pajnik, Bajt 2011), attest to the constriction and discriminatory effects of migration policies in Slovenia. However, there are no analyses that systematically study migration policies in Slovenia from the perspective of crimmigration, let alone employ a critical comparative perspective with the country's international law commitments. There is a lack of analysis of procedures related to crimmigration, such as border control and deportations. Highlighting the continuity in the way in which the outsiders have been framed as Others and governed throughout the centuries, we focus on Slovenia as a case study. ${ }^{1}$ No crimmigration research exists in Slovenia, thus the paper

1 Weber and Bowling (2008), for instance, describe the $18^{\text {th }}$ century laws in the UK that restricted the mobility of "masterless men", paupers and beggars, while history is full of examples of excluding the Other, most notably Jews and Roma. 
serves as an initial comprehensive overview of the current situation. Our approach to the criminalization of migration is sociological and focuses on "discoursive crimmigration" (Parkin 2013). We are not interested in scholarship that examines the issue of "migrant criminality", as our concern is with the societal trend of constructing migrants as symbolic assailants, particularly in view of their constructed Otherness. Rather than merely providing an account of existing laws, policies and procedures, we therefore seek to understand the consequences of increased deployment of criminal justice measures to address the "immigration problem" as they manifest in socio-economic exclusion and the denial of migrants' human rights.

\section{METHOD AND OUTLINE}

The paper draws on interviews conducted with the main actors involved in crimmigration procedures: key stakeholders such as state representatives, non-governmental organizations and migrants. ${ }^{2}$ The situations and experiences of migrants are very different; some entered Slovenia legally, some irregularly. In this way, we are able to associate policy measures as envisioned by state actors with their immediate effects both in the form of implementation by public employees in charge of enforcing the law (e.g. the police) and in the form of crimmigration consequences as experienced by the target of its measures - the migrants themselves. We employ desk analysis of policies and the interview analysis method. Empirically, the paper draws on 12 detailed semi-structured interviews conducted between November 2017 and April 2018 with main actors involved in crimmigration procedures (see Tables 1 and 2).

Table 1: Migrants

\begin{tabular}{|c|c|c|c|c|c|}
\hline Pseudonym & Gender & Age & $\begin{array}{c}\text { Year of arrival in } \\
\text { Slovenia }\end{array}$ & $\begin{array}{c}\text { Country of } \\
\text { birth }\end{array}$ & Status \\
\hline Samar & female & 23 & 2016 & Syria & Refugee \\
\hline Amine & male & 23 & 2015 & Algeria & $\begin{array}{c}\text { Asylum } \\
\text { seeker }\end{array}$ \\
\hline Peter & male & 47 & 2010 & Jamaica & $\begin{array}{c}\text { Permanent } \\
\text { residence }\end{array}$ \\
\hline Aisha & female & 33 & 2016 & Morocco & $\begin{array}{c}\text { Temporary } \\
\text { residence }\end{array}$ \\
\hline Esek & male & 22 & 2017 & Eritrea & Refugee \\
\hline Zahim & male & 29 & 2014 & Afghanistan & $\begin{array}{c}\text { Asylum } \\
\text { seeker }\end{array}$ \\
\hline
\end{tabular}

2 For the purpose of greater clarity we adopt official terminology where needed but use the general term "migrant" to signify the mobility of people as free agents beyond their ascribed status. 
Table 2: Stakeholders

\begin{tabular}{|c|c|c|}
\hline & Sector & Date of interview \\
\hline INT1 & Ministry of the Interior & 28.03 .2018 \\
\hline INT2 & Ministry of the Interior & 16.04 .2018 \\
\hline INT3 & Ministry of the Interior & 16.02 .2018 \\
\hline INT4 & Police & 21.02 .2018 \\
\hline INT5 & Police & 26.01 .2018 \\
\hline INT6 & Civil society & 23.11 .2017 \\
\hline
\end{tabular}

The first section provides an overview of discoursive crimmigration, followed by elucidating Slovenia's priorities in terms of migration management and control in the second section. The third section summarizes the main consequences of crimmigration in Slovenia, concluding that the wider EU framework is essential for understanding the current state of affairs, as well as the best predictor of future trends in this regard.

\section{DISCOURSIVE CRIMMIGRATION}

The criminalization of migrants (and ethnic minorities) includes "all the discourses, facts and practices made by the police, judicial authorities, but also local governments, media, and a part of the population that hold immigrants/aliens responsible for a large share of criminal offences" (Palidda 2011: 23). Considering the overrepresentation of non-nationals and ethnic minorities in the criminal justice systems of European member states on the one hand and public perceptions increasingly linking migrants to crime on the other, there is a conspiquous "lack of any concrete empirical evidence substantiating a correlation between immigration figures and crime rates" (Parkin 2013: 2). Research (Palidda 2011) found no links between the intensification of criminalisation trends in specific national contexts and increasing crime rates or immigration, meaning no "correlation in the criminalisation of aliens and rises in crime" could be confirmed, yet interestingly "periods of economic difficulty often see the fiercest proliferation of criminalisation discourses and surges of xenophobia" (Parkin 2013: 3). In Slovenia, a rise in xenophobia and anti-immigration hate speech has been linked to the socio-economic effects of the 2008/2009 financial crisis (Pajnik, Bajt 2010). Moreover, research confirms that most immigrants integrate, yet factors such as proliferation of immigration-related criminal offences and discriminatory treatment by police (e.g. ethnic profiling) artificially amplify the statistical representation of migrants and minorities in criminal activities (Parkin 
2013: 2). Analysing the discoursive aspect of criminalisation thus facilitates an understanding of the complex social and political conditions that allow the construction of migrants as symbolic assailants.

Moreover, the ways in which the media portray migrants, combined with a political rhetoric of fear, lead to actual crimmigration policies. The discursive dimension of the criminalization of migration therefore exceeds the field of criminal law, referring to the way in which the rhetoric on immigration and security constructs the idea of fear/threat which is automatically associated with migrants as deviant and immigration as a security risk (Maneri 2011). Consequently, migrants are constructed as threatening the social order, "our" jobs and wellbeing, which therefore warrants strict(er) immigration control regimes (Provine, Doty 2011). The role of the mass media perpetuates crimmigration in society and negatively affects public opinion and the legal certainty of migrants. In particular, social media platforms enable an unprecedented fast spreading of fake news, using prejudice in order to disperse the politics of fear and creating a constant state of anxiety through media panic that reduces public space for a competent and critical assessment of migration policies. At the same time, "media logic" follows political agendas, as the media favour dominant sources, in particular the political and economic elites, who thence obtain a platform for the dissemination of dogmatic, populist and nationalist statements (Pajnik 2017). While the media in Slovenia was paying full attention to refugee arrivals during the first two months of the 2015 "refugee crisis", for example, migration started disappearing from the news as well as from public discourse, only to reappear in time for the parliamentary electoral campaign in the spring of 2018. The media spectacle of the first few weeks of the 2015 mass migration was exceptionally similar to any other crisis reporting and helped instil fear and intolerance among the Slovenian public. Without the media coverage, most residents of Slovenia would have no idea refugees were even in the country, since their contact with the local population was restricted to a bare minimum (Kogovšek Šalamon, Bajt 2015).

Space limitations here preclude an analysis of the role of the media in strengthening crimmigration, but ample research confirms the immense importance of analysing the mediatization of migration (Maneri 2011; Pajnik 2017), i.e. how the media report on migration, how they select sources, who speaks in the media and why, what is the editing policy concerning the issue of migration and what is the impact of the media on public opinion and consequently on the drafting of legal provisions. Suffice it here to note that the mass media play an important role in crimmigration, creating media panic through hegemonic discourse that is problematically focused on national security in case of the arrival of migrants, thus creating and consequently exercising public pressure that pushes for stricter legal regulation, strengthening of border control and lack of readiness to assist people in need. 


\section{MANAGING MIGRATION}

When researching migration management priorities, one must take into account that "migration processes are of a long-term nature, while the policy-cycle is essentially short-term and often determined by the length of electoral periods" (Castels 2010: 223). In addition,

the declared objectives of states are often quite misleading. They are driven both by the need to maintain legitimacy and the unwillingness to face up to past policy failures. Policies that claim to exclude undocumented workers may often really be about allowing them in through side doors and back doors, so that they can be more readily exploited. (ibid.)

Refugees started arriving in Slovenia in increased numbers in September 2015, and when Hungary's borders were finally closed, they could enter Austria only from Slovenia. Using this "corridor", according to the official police statistics, 396,240 migrants entered Slovenia between 17 September 2015 and 7 January 2016. Since only a handful of them applied for asylum and almost none were successfully returned by the police, almost the same number of people left Slovenia heading for Austria and other western and northern European countries. The total number of applicants for international protection in Slovenia in 2018 was 1,430 (1,304 men and 126 women), but only 53 persons received international protection status.

According to data from the Government Office for the Support and Integration of Migrants, on 29 October 2018 there were 641 people with recognised internationally protected status in Slovenia, 278 asylum seekers (most of whom were housed at the Asylum centre), and 97 persons were waiting to file an application (UOIM 2018). The police statistical data shows that there were 1,930 irregular migrants apprehended in the territory of the Republic of Slovenia in 2017, and the number increased from 1 January to 30 September 2018 to 6,667 "unauthorised border crossings" (Policija 2018: 1). In regard to crimmigration processes, the police identified

693 violations committed by foreigners who had illegally entered Slovenia on its internal border without possessing a proper travel document or permit (e.g. residence permit or visa). The corresponding figure last year was 739 . This represents a 6.2 per cent decrease in comparison with the same period last year" (ibid.: 2).

These numbers indicate the primary criminal charges related solely to migration. The combination of migration and criminal law thus leads to increased representation of migrants in prisons and in public discourse, which serves as additional evidence of higher criminality of immigrants (Učakar 2017: 60). 
It is impossible to analyse Slovenia's crimmigration policies and practices without first highlighting its role as an EU member state that borders Italy, Austria, Hungary and Croatia. The border with Croatia is a Schengen border that Slovenia is bound to uphold and protect. Examining the elements of criminalization of migration as they appear in the legal framework, institutions and policies in Slovenia, is therefore entwined with their accord (or lack thereof) with EU and international norms. The Aliens Act and its amendments (last changed in 2017) refers to removal of an alien, seizure of an alien's travel document, irregular border crossing, assistance in irregular border crossing, irregular retention in the country and identification. Irregular border crossing and assistance with irregular border crossing are also covered by the State Border Control Act and some aggravated forms also in the Penal Code and its amendments, where the severity of the punishments for these criminal offenses was increased in the most recent changes that were made in 2017. According to the Minister of the Interior, some of the most recent changes were made in response to the European Commission's initiative that Slovenia would become a new hotspot (MMC 2017). Hotspot means that all the responsible EU agencies (e.g. Frontex, Europol, Eurojust) work on the ground with the authorities of frontline member states facing disproportionate migratory pressures along the EU's external borders. The idea is to help them fulfil their obligations under EU law and swiftly identify, register and fingerprint incoming migrants. Faced with this prospect, Slovenia's authorities described the situation from 2015 onward as a "full red alert" (ibid.), and adopted legal measures that would safeguard Slovenia from ever again becoming a hotspot. Mirroring measures adopted over the past three years by neighbouring Hungary and Austria, in January 2017 Slovenia approved a bill that allows police to seal the border with Croatia. Under the new legislation, Slovenian authorities can reject asylum seekers directly at the frontier with non-Schengen member Croatia in case of a new influx of migrants which could "threaten public order and internal security." The Prime Minister and Minister of the Interior stated at the time that it was an "extreme measure" that the government had to draft in case it would ever be needed again (ibid.). Such fear-inducing tactics were augmented a month later at the EU Malta summit, where the head of Slovenian government warned that a new migration route had opened across the Adriatic Sea towards Istria, even though the data of the Slovenian and Croatian police did not confirm this (Gaube 2017).

Migration policy in Slovenia is centralized, since most of the measures are implemented at the level of the Ministry of the Interior, which is responsible for asylum and migration. ${ }^{3}$ A number of other ministries are also involved, each in the implementation of individual procedures related to its departmental jurisdiction. Local

3 In July 2017, a special Government Office for the Support and Integration of Migrants (sl.: Urad vlade za oskrbo in integracijo migrantov - UOIM) was established, taking over part of responsibilities that were previously under the authority of the ministry. Devising policies and administrative procedures for obtaining the status of international protection remain under the jurisdiction of the Ministry of the Interior. 
communities do not have formal power to implement asylum and migration measures, though integration is in actuality conducted at the local community level and sustained by various non-governmental sector programmes. Slovenia as an EU member state actively participates in EU migration policymaking and in the implementation of EU legislation. The migration management system comprises criminalization, including sanctions for irregular border crossing, (joint) expulsions, and restriction of movement as primary criminal charges. Below, we identify three key points regarding Slovenia's migration policy as they relate to the theme of crimmigration.

\section{Migration Policy Priorities}

According to the analysis of the policy and the analysis of the interviews that we conducted, Slovenia tries not to stand out in terms of the European average, and mainly follows the lead of other countries. The interviewees note that no specific policy goals or priorities exist and that positions shift and priorities are created ad hoc. While migration policy, if one can be said to have existed prior to the events of 2015/16, was stagnant and no major problems were identified on the part of state officials, the "refugee crisis" changed all that:

First we saw something like a humanitarian approach, but then we went into state protection, so the fence was a priority [...] Nobody is setting any special priorities in this broader sense, it is actually just a response to the current situation [...] There is no migration policy in Slovenia at all. With this wave of 2015/16, when many migrants came, it seems to me that some positive movements occurred due to the fact that individual institutions began to realize "ah, we have refugees in Slovenia" although refugees have been in Slovenia since 1995. This may have been a positive shift that at least one started to think differently, to look for some systemic or at least temporary solutions, improvements. On the other hand, there was the negative shift of polarization of Slovenia, the criminalization of this population. (INT2)

In terms of legal immigration, economic migration can be recognized as Slovenia's priority in respect of the need for a migrant workforce in certain sectors due to labour demand, most notably in construction. The number of new work and residence permits issued is high every year, especially among citizens of the former Yugoslav republics. However, a proactive migration policy that would address the shrinking numbers of the working-age population is not a priority, despite listing integration as a keyword. "Integration is definitely a priority which has been repeatedly expressed [...] As far as illegal immigration is concerned, the Western Balkans is a priority by building the capacities of the countries on the natural pathway of illegal immigration through Slovenia." (INT1) 
The Slovenian police are actively involved in Frontex operations and implement wider EU immigration control policies, but the state's emphasis is primarily on the regional neighbourhood, especially since the 2015 events that brought the Balkan route into focus:

The European Union was really very inefficient with its measures. The fact is that legislation was simply not adapted to the situation that we were faced with. At that moment we really saw the importance of regional cooperation. Of course, in our case regional cooperation doesn't only mean cooperation with EU member states but regional cooperation for us is chiefly cooperation with Balkan countries. (INT1)

\section{The EU and Schengen}

Based on the European Union treaties, migration legislation and policy are in the domain of the European Union. After the Treaty of Lisbon, both the EU Council and the European Parliament act as decision-makers, while the European Commission is the body that proposes measures at the European Union level. In 2016, the European Commission presented a reform legislation package, i.e. a set of changes to the Common European Asylum System. The proposed statutes underwent various negotiation stages, where the recasting of Dublin Regulation is the most important, suggesting a potential new crisis management mechanism for situations where one or more EU member states are facing "challenging circumstances" or "severe crisis". From this perspective, a (re)new(ed) legislative framework is being developed in the EU.

The decision-making process in Brussels has changed a lot since the 2016 migration crisis. The European Commission used to have greater weight with its proposals which it ultimately implemented. But during the crisis this role was taken over by the European Council. And the actual decisions were very political. And here's a twist from before when it was the technocracy who knew the legislative framework, who were preparing things. But now, this political takeover through legal mechanisms, it greatly influences the way things operate in Brussels. So, in my opinion, unfortunately, we do not get anywhere with certain ideas because they simply cannot be accepted politically. (INT1)

Due to Slovenia's geographic position, its southern border with Croatia is now a Schengen border, and this fact governs its foreign policy in terms of asylum and overall migration management.

In all documents, Slovenia stands for the protection of the external borders of the European Union. And no distinctions are made between the external Schengen border and the EU's external border. Slovenia always emphasizes the need to protect 
the borders on the external boundary of the EU. It is clear which borders this refers to. (INT1)

Formally, Slovenia claims to be in favour of mutual solidarity among member states, as demonstrated by its participation in the relocation mechanism which was established as a consequence of the "migration crisis". It has recently joined the resettlement programme, and data show that out of its legal commitment to host 567 people, 253 persons were relocated to Slovenia by July 2018 (81 from Italy and 172 from Greece). One of our interviewees, a 23-year-old woman, started in Syria together with her family. Her story reveals a typical Balkan migratory route: first they went to Turkey and continued to Greece by boat. Eventually they travelled to Macedonia, and were finally transferred to Slovenia based on the EU quota system:

It was really, really bad where we lived. We lived in Aleppo, where there was a lot of bombing. We left everything [...] we wanted to go to Germany because in Syria we heard that Germany had opened the borders for refugees. We didn't know any other country. We had never heard of Slovenia before [...] We came to Turkey, after that we went to Greece by boat [...] It was very difficult and really bad. When we came, my baby was 14 days old. He was crying a lot, very scared and it was really dangerous [...] We stayed in Greece for 9 months. We stayed in a tent at the border for 3 months and they didn't open the border [...] The government in Greece said that all refugees will go to other countries when they open the border [...] In Macedonia it was really, really bad [...] [The officials] would just ask "when and why did you come" [...] They wrote my name, my children's names and they took pictures. After two months they called and said "you will go to Slovenia". (Samar)

With regard to the European Commission's plans to redistribute refugees throughout the EU, which caused a major rift inside the union, Slovenia shifted its stance from voluntary to mandatory acceptance of the refugee quota among member states.

\section{Political Climate and Pushbacks}

Developments at the EU level run in parallel with national events. Especially the pre-election periods in member states show there is a lot of emphasis on migration policy and refugees, as well as debates on integration and a tendency to delimit people who need protection and those who allegedly do not and are seen as cheats (i.e. "economic migrants"). The shift of the debate on migration is visible and has been observed in all our neighbouring countries that have already had elections, i.e. Austria, Italy and Hungary. Migrations were also one of the central pre-election themes in Slovenia during the spring and summer of 2018, and the role of politics in migration policy creation is clear. 
The amendment to the International Protection Act was primarily the result of adapting to the European acquis and was not conditioned or encouraged by national policies, though "certain solutions" that were introduced at the time it was amended "may be the result of a political environment of the time" (INT1). An analysis of the existing policies shows that in theory an individual has the right to access the asylum procedure and claim protection in EU member states. However, the definition of a refugee has become too narrow for all the groups that seek refuge from threatening circumstances or wish to escape from economic exploitation and despair. The 2015 "refugee crisis" is a reflection of the inability of the state and international law to provide protection for all those in need. All EU member states have ratified the Geneva Convention and are bound by EU asylum and migration law, which sets forth basic guarantees for people seeking protection. However, in practice, access to asylum is difficult and most people are forced to attempt to access the EU territory by means of irregular entry. This is to say that legal access to the territory has become practically impossible.

With the mass migration of autumn 2015, Slovenia had found itself in a completely new situation in which the normative framework in place in the field of migration could no longer function. The government's insistance on the strict implementation of the legal rules that were generally in place for such situations was completely inappropriate for the increased arrivals of people who desperately wanted to move on, crossing Slovenia on their way from Turkey/Greece/Western Balkans towards Germany. Eventually, the government had no other recourse but to implement a practice that already existed in Macedonia, Serbia and Croatia - a humanitarian "corridor". In this way, the state allowed people to enter Slovenia and receive basic reception conditions but continue their travels towards Austria, even if they were without documents (for a detailed analysis see Kogovšek Šalamon 2017). At the same time, the governmental discourse turned into one of the "security" of local people and their property and the "protection" of national interests. The humanitarian aspect of the "refugee crisis", to which the government discourse was at least still paying lip service in August 2015, was gone within a month and has not returned since, being progressively and steadily replaced by crimmigration measures and anti-migration rhetoric that is stronger than ever in 2018. Moreover, viewing migrants as symbolic assailants has become a pervasive stance among public servants whose work puts them in close proximity of crimmigration practices as part of their job. A border police officer thus reflects:

If you permit free circulation across [borders], in a year, two, three, there'd be chaos in Europe, in Slovenia. Europe can help, but it can't help in a way that the whole of Asia, Middle East, Africa move here and live on social transfers. It's impossible. It's simple: each country can help a portion of people when in real need, but not the whole continent, no. 
While aware that it is not the police prerogative to resolve asylum applications, having been in contact with many migrants, our interviewee feels he knows the actual situation:

After so many years we see who is justified and who isn't entitled. So, there's abuse, exploitation, asylum is being exploited. The problem is that then it's those who need it the most who must either wait too long or don't even get it because of others who are basically exploiting it. And they are all, almost everyone is exploiting it now. (INT5)

It is in fact not uncommon for public servants to speak of "asylum shopping", which testifies to the official stance towards migrants as devious. Even more problematic, for migrants who have the right to international protection from persecution and serious human rights violations, so-called pushbacks stand in the way of seeking protection and enjoying their right to an individual assessment of their claims. Pushbacks are happening in various ways, but brutality, intimidation and devious tactics by authorities have been widely documented to engender a climate of fear and mistrust amongst people on the move. In 2018, reports about pushbacks in Slovenia also appeared (Amnesty International 2018; Regvar 2018; Videmšek 2018). The Ombudsman's office also found cases where the personal circumstances of migrants who might be able to apply for asylum were ignored or not seriously considered by the police in the process of apprehending irregular border crossers (MMC 2018).

Amnesty International and PIC both reported that in June 2018 the Slovenian authorities restricted access to asylum and forced the return of several migrants. Data was obtained in Velika Kladuša and Bihać in Bosnia from witnesses who, although they wanted to claim asylum in Slovenia, were returned to the Croatian authorities. Unlike the Slovenian police, the Croatian authorities do not enact a formal return to Bosnia but simply drive the migrants to the vicinity of the border and leave them there; reports indicate that they are forced to cross the border. Official police statistics confirm a change in practice in June 2018: despite the fact that the number of people who crossed the border in an illicit manner decreased, returns to Croatia increased markedly. At the same time, the number of people who were recorded by the police as having expressed the intention to apply for asylum fell drastically. Since the situation for refugees in Bosnia is worrisome, the NGO watchdogs conclude that Slovenia is in breach of the non-refoulement principle (Regvar 2018).

\section{CONSEQUENCES OF CRIMMIGRATION}

Research shows that border control intensifies at times of structural change when institutions capable of preserving the emerging economic and social order are largely absent (Weber and Bowling 2008). In a globally mobile society, "suspect citizens" 
(ibid.) and outsiders, such as migrants, are the most likely to be earmarked for exclusion. "This designation links historical conceptions of 'the other' with the tropes of race, class and foreignness to underpin contemporary xeno-racism" (ibid.: 355).

The previous section noted that understanding the wider EU framework is essential for understanding the current state of affairs regarding crimmigration trends in Slovenia: "All of a sudden they started to cut some rights and [Slovenia] blindly followed: "yes, we also need to do something" and they unnecessarily abolished the onetime monetary assistance [to refugees], which was the key to starting integration, that someone could make this transition. And this was a purely political decision" (INT2).

Even though state authorities describe current migration policy trends as increasing the rights of asylum seekers and other migrants in terms of more emphasis placed on integration measures, members of civil society, migration researchers and public servants with actual field experience oppose this view by elucidating many areas of tightened control and clamping down on migrant rights. Officially, at least 12 people have died so far attempting to cross the border (Videmšek 2018). Many interview respondents believe that general migration and refugee policy is becoming more stringent. "Generally I could say yes, yes, it's getting stricter and ... of course politicians always use it for their own purposes" (INT2). Crossing the border into Slovenia, both physically and in terms of stricter control, has clearly become more difficult. "Ever since the migrant crisis it has been getting more difficult, the very act of crossing the border is harder; with the closing of the borders and with actions of other states" (INT5). At the same time, states have improved cross-border cooperation with the aim of better border policing and adhering to the Dublin convention.

Asylum is getting harder to get. There are many more checks. In Slovenia it's getting worse. Maybe they don't say this on TV, but it's getting harder. They first put up a fence. Now they made this centre in Brežice, the EU gave the money. In this centre we now have a police officer who has 4 monitors, and the 4 monitors are divided into 4 images, 16 cameras. (INT5)

On the other hand, the official stance is that migration and asylum policy are not becoming stricter:

I think it's hard to talk about becoming stricter. Certain measures within migration policy show that the EU, and so also Slovenia, began to realize that it's better for everyone, including those arriving legally, to have regulated immigration and, on the other hand, a reduction of illegal immigration. Because we cannot stop it, we'll never be able to stop it ... The set of rights, protection, legal remedies in certain procedures, these are only increasing. The policies are not becoming stricter, so this is forcing some countries that are most affected to adopt certain actions or measures that are intended to suppress or restrict [migration]. But this remains at the national level, there are definitely no policies of aggravation at the EU level. (INT1) 
State officials like to say that "things are also changing for the benefit of foreigners and refugees" (INT3). And watchdog organizations and several migration researchers would agree that legal framework in Slovenia is "good in many respects" (INT6). However, while matters seem fine on paper and some procedures also run smoothly in practice, there are still many shortcomings that make the system problematic. Lengthy procedures in processing asylum applications are one such example, as are inconsistencies in judicial decisions that make decisions on asylum applications "a lottery" (ibid.), which makes counselling a difficult task, since outcomes are extremely unpredictable: "One really big problem is asylum backlogs, which have come to the fore due to the increased number of applications. But the problem of slow decision making already existed before" (ibid.).

The bureacratic obstacles experienced by migrants have been widely documented (Pajnik and Bajt 2010), and are also confirmed by our interviewees. Aisha from Morocco reported having trouble extending her documents. Even though she had a Schengen visa, she faced various obstacles in arranging her residency after getting married in Slovenia. She notes there was a period she had to live in Slovenia illegally. Peter from Jamaica also shared his experiences with official procedures: "I realised that it's a very difficult place to live if you are a foreigner. This society is very discriminative." Conversely, Esek started his migration from Eritrea, passing Ethiopia, Sudan, Libya, Turkey, Greece, Macedonia, Serbia, Croatia, Slovenia and Austria. In comparison, his first impression of Slovenia and its procedures was good: "I can say it's really good and people friendlier than in other countries." He was imprisoned in Austria and his assessment of restriction of movement succinctly sums up what crimmigration is all about - criminalizing people for the mere act of migrating: "It was in Austria because l escaped to countries without documents. This is the system, a really very bad system in Europe ... Immigrants, they don't do anything, you know. Like me, I did nothing, I don't sell drugs, I don't do anything [wrong]. They just put me in prison, you know, because of a very bad system in Europe (Esek).

One interviewee presented himself primarily as a person, a human being, regardless of his current status or birth country. He entered Slovenia irregulary (by train) after attempting to reach Italy for the fourth time. He notes having very good experiences with the border police, despite being captured, and sums up his human existence, formally bound by crimmigration measures, perfectly: "My life is actually outside these walls" (Amine).

\section{CONCLUSION}

The paper is an attempt to fill a gap in crimmigration research in Slovenia, serving as a first comprehensive overview of the current situation. Rather than researching "migrant criminality", our approach to the criminalization of migration was sociological and our focus was on the societal trends of constructing migrants as symbolic 
assailants. Analysing the consequences of increased deployment of criminal justice measures to address the "immigration problem", the paper emphasizes how they reproduce socio-economic exclusion and the denial of migrants' human rights. We examine whether migration policy in Slovenia is becoming stricter in the direction of increased criminalization of migration and to what extent these trends may be a consequence of the implementation of wider EU policies, arguing that understanding the wider EU framework is essential for understanding the current state of affairs, as well as the best predictor of future trends. We show how the political leadership and competent institutions in Slovenia reproduce crimmigration on the basis of ideologemes of national security, the protection of the "local" population, and the incompatibility of migrants as different, as outsiders. In doing so, the paper concludes that the implementation of crimmigration policies such as border control and pushbacks have discriminatory effects that augment the rightlessness of migrants. In the context of the role of Slovenia as an EU member state managing the EU border, our findings resonate with a broader issue of crimmigration in Europe and beyond.

Empirically, the paper draws on interviews conducted with the main actors involved in crimmigration procedures: state representatives, non-governmental organizations and migrants. The main part of the paper thus offers an analysis of the position and viewpoint of the key stakeholders on crimmigration policies - their perspectives of the migration management system, institutions and procedures, how they assess this experience and what their policy proposals are. We were thus able to associate the policy measures as envisioned by state actors with their immediate effects both in the form of implementation by public employees in charge of enforcing the law, as well as in the form of crimmigration consequences as experienced by the targets of its measures - the migrants themselves.

The criminalization of migrants is "currently written into a neoliberal/neoconservative political framework based on the asymmetry of power and wealth between actors that are all-powerful, and weak ones who have no rights" (Palidda 2011: 2). In conclusion, we wish to reiterate that much of contemporary migration, especially the so-called migration crisis, represents an integral aspect of North-South relations, and any

policy in this area is doomed to failure unless it addresses the causes of both economic and forced migration in current patterns of global inequality [...] The vast disparities of wealth and power in the emerging global order mean that not all citizens are equal and that some passports are better than others. Such hierarchies may be the basis of a new system of global economic stratification, in which migration - in all its guises - is a key element. In this context, migration control is really about regulating North-South relationships and maintaining inequality. (Castels 2010:223)

In these processes Slovenia is part of a wider geographical and political framework, which means that using law and policy in Slovenia as a case study can provide a 
better understanding of the wider EU context. Nevertheless, we could offer only a limited overview of crimmigration processes, and further research is needed that would employ a critical comparative perspective with Slovenia's international legal commitments. There is also a lack of analyses that would study the responses of political elites and competent institutions in relation to specific migration topics, as well as analyses of certain procedures related to crimmigration in Slovenia, such as the further examination of border control, ethnic profiling, pushbacks and deportations.

\section{REFERENCES}

Amnesty International Slovenije (2018). Vračanja in omejevanje dostopa do azila v Sloveniji, http://www.amnesty.si/prisilna-vracanja (19. 7. 2018).

Castels, Stephen (2010). Why Migration Policies Fail. Ethnic and Racial Studies 27/2, 205-227.

Franko Aas, Katja (2013). The Ordered and the Bordered Society: Migration Control, Citizenship, and the Northern Penal State. The Borders of Punishment: Migration, Citizenship, and Social Exclusion (eds. Katja Franko Aas, Mary Bosworth). Oxford: Oxford University Press, 21-39.

Frelich, Bill, Kysel, Ian M., Podkul, Jennifer (2016). The Impact of Externalization of Migration Controls on the Rights of Asylum Seekers and Other Migrants. Journal on Migration and Human Security 4/4, 190-220.

Gaube, Aleš (2017). »Trdnjava Evropa« se zapira tudi proti Libiji, Cerar pa si izmišlja nove migracijske poti na Jadranskem morju. Dnevnik, https://www.dnevnik. si/1042761889 (4. 2. 2017).

Jiang, Jize, Erez, Edna (2018). Immigrants as Symbolic Assailants: Crimmigration and Its Discontents. International Criminal Justice Review 28/1, 5-24.

Kogovšek Šalamon, Neža (2011). Migration Law in Slovenia. Alphen aan den Rijn: Kluwer Law International.

Kogovšek Šalamon, Neža (2017). Mass Migration, Crimmigration and Defiance: The Case of the Humanitarian Corridor. Southeastern Europe 41, 251-275.

Kogovšek Šalamon, Neža, Bajt, Veronika (eds.) (2016): Razor-wired: Reflections on Migration Movements through Slovenia in 2015. Ljubljana: Peace Institute.

Maneri, Marcello (2011). Media Discourse on Immigration: Control Practices and the Language We Live. Racial Criminalization of Migrants in 21st Century (ed. Salvatore Palidda). Farnham: Ashgate, 77-94.

MMC (2017). Zakon o tujcih ob podpori opozicijskih SDS-a in NSi-ja sprejet s 47 glasovi, http://www.times.si/slovenija/v-zivo-dz-razpravlja-o-tem-koliko-davkoplacevalce-stane-vsak-migrant--e879d483543e2f71ec4e1f936e5ec5e2dd009fff.html (26. 1. 2017).

MMC (2018). Urad varuha človekovih pravic: Policija v Črnomlju in Metliki zanemarja osebne okoliščine prebežnikov, https://www.aktualno24.si/view/varuh-policija- 
-v-crnomlju-in-metliki-zanemarja-osebne-okoliscine-prebeznikov-310qz98pdoy4qn1oex416wj5 (22. 8. 2018).

Pajnik, Mojca (2017). Medijsko-politični paralelizem: Legitimizacija migracijske politike na primeru komentarja v časopisu »Delo«. Dve domovini / Two Homelands 45, 169-184.

Pajnik, Mojca, Bajt, Veronika (2010). Migrant Remittances in Times of Economic Decline: Coping with Protectionist Policies in Slovenia. Migration Letters 7/2: 179-189.

Pajnik, Mojca, Bajt, Veronika (2011). 'Third Country' Migrant Workers as 'Third Class Non-citizens' in Slovenia. Precarious Migrant Labour across Europe (eds. Mojca Pajnik, Giovanna Campani). Ljubljana: Peace Institute, 97-118.

Palidda, Salvatore (2011). A Review of the Principal European Countries. Racial Criminalization of Migrants in 21st Century (ed. Salvatore Palidda). Farnham: Ashgate, 23-30.

Parkin, Joanna (2013). The Criminalisation of Migration in Europe: A State-of-the-Art of the Academic Literature and Research. CEPS Liberty and Security in Europe No. 61/2013.

Peters, Margaret E. (2017). Trading Barriers: Immigration and the Remaking of Globalization. Oxford: Princeton University Press.

Policija (2018). Nedovoljene migracije na območju Republike Slovenije, https://www. policija.si/images/stories/Statistika/MejnaProblematika/llegalneMigracije/2018/ Illegal_migration_EN/January-September_2018.pdf (1. 11. 2018).

Provine, Doris Marie, Doty, Roxanne Lynn (2011). The Criminalization of Immigrants as a Racial Project. Journal of Contemporary Criminal Justice 27, 261-277.

Regvar, Urša (2018). Poročilo o ugotovitvah in opažanjih o izvajanju postopkov vračanja in spoštovanja načela nevračanja (non-refoulement). Ljubljana: PIC.

Stumpf, Juliet (2006). The Crimmigration Crisis: Immigrants, Crime, and Sovereign Power. American University Law Review 56/2, 367-419.

Učakar, Tjaša (2017). Migracijska politika EU: Nove artikulacije izključevanja v 21. stoletju. Ljubljana:Filozofska fakulteta.

UOIM (2018). Aktualni podatki: Pregled stanja nastanitev na dan 29. 10. 2018, http:// www.uoim.gov.si/si/statistika/aktualni_podatki/ (1.11. 2018).

Videmšek, Boštjan (2018). Smrt v Kolpi, https://www.delo.si/sobotna-priloga/smrt-v-kolpi-70777.html (14. 7. 2018).

Weber, Leanne, Bowling, Benjamin (2008). Valiant Beggars and Global Vagabonds: Select, Eject, Immobilize. Theoretical Criminology 12, 355-375.

Zorn, Jelka (2014). 'No Border, No Nation, Stop Deportation': Protest against Immigration Control as Empowerment. Critical and Radical Social Work 2/2, 175-192. 


\section{POVZETEK}

\section{KRIMIGRACIJE V SLOVENIJI Veronika BAJT, Mojca FRELIH}

Avtorici v članku obravnavata »krimigracijo (tj. kriminalizacijo migracij) v Sloveniji. Raziskujeta elemente kriminalizacije migracij v pravnem okviru, institucijah in politikah. Uokvirjanje tematike na normativni ravni, tj. na ravni institucij, analizirata skupaj s pregledom izvajanja konkretnih postopkov v praksi. Analizo političnih in strokovnih mnenj tako združujeta $z$ analizo učinkov, ki jih imajo krimigracije na migrante in migrantke. Empirični del članka temelji na dvanajstih poglobljenih polstrukturiranih intervjujih. Izkušnje oseb, ki migrirajo, s krimigracijskimi ukrepi namreč dodatno potrjujejo, da migracijska politika v Sloveniji, tudi kot posledica izvajanja smernic EU, postaja strožja in vedno bolj usmerjena v povečevanje kriminalizacije migracij.

Prispevek je prvi celoviti pregled stanja in zapolnjuje vrzel v raziskavah kriminalizacije migracij v Sloveniji. Pristop h kriminalizaciji migracij je sociološki, poudarek pa na aktualnem trendu konstrukcije migrantov kot »simboličnih napadalcev« oziroma kršiteljev zakona. Z analizo posledic povečane uporabe ukrepov kazenskega pregona za obravnavo »problematike migracij« članek ponazarja socialnoekonomsko izključenost in zanikanje človekovih pravic migrantk in migrantov. Avtorici raziskujeta, ali migracijska politika v Sloveniji postaja strožja in gre v smeri povečane kriminalizacije migracij, v kolikšni meri gre za posledico izvajanja širših politik EU oziroma koliko je širši okvir EU bistven tako za razumevanje sedanjega stanja kot tudi za napovedovanje prihodnjih trendov. Izvajanje krimigracijskih politik, kot sta npr. povečan nadzor meja in prisilno vračanje, povzroča diskriminacijske učinke in nespoštovanje pravic migrantov. V kontekstu vloge Slovenije kot države članice EU, ki upravlja zunanjo šengensko mejo, so ugotovitve avtoric odsev širših vprašanj krimigracijskih procesov $v$ Evropi in drugod. 